\title{
Giving Creativity Room To Students Through The Friendly School's Program
}

\author{
Bukman Lian, Muhammad Kristiawan, Rosma Fitriya
}

\begin{abstract}
The creativity of children will be able to grow whether the school can provide space for creativity. Child-friendly schools are school concepts that give protect students from violence, discrimination and unnatural treatments. It provides assurance and fulfill the rights of students such giving students space for creativity. This research was conducted at SD Negeri 109 Palembang. This study aimed at determining how the school provides creativity space to students through child friendly school's program. This research was descriptive qualitative, which investigate how to give creativity room to student in a child friendly school's program. The instruments of collecting data were interview, documentation, and observation. The results obtained indicate that the school provided space for students' creativity through learning strategy and school's environment approach. Based on this program, the students at SD Negeri 109 Palembang have been able to show their creativity attitude through problem solving while in learning activities and outside learning activities. Child-friendly schools should ensure every student's opportunity to enjoy his/her rights in education without discrimination based on disability, gender, ethnicity, religion, type of intelligence, and parental background. Child-friendly schools should also consider safe, clean and healthy school situations, caring and cultured, living environment, respect the rights and protection of students from violence, discrimination and other unfair treatment, and ensure the participation of students in planning, policy, learning, supervision, and complaint mechanism related to the fulfillment of rights and protection of students in education.
\end{abstract}

Index Terms: Creativity Room, Friendly School's Program, Primary School.

\section{Introduction}

THIS article is based on the results of a survey by the Indonesian Education Sector Survey Report, which states that education in Indonesia still emphasizes on mere routine and rote skills (Juliantine, 2009). Then, Pusitaningtyas (2016) suggests that what has been developed through education today is the ability to think linear, exact and logical. Left hemispheric brain functions such as linear, exact, rational and reasoning skills are under great pressure in educational practices. While the right hemisphere of the brain which concerns the ability of holistic thinking, imaginative, intuitive and creative still get less attention (Pusitaningtyas, 2016). The formal education system in Indonesia in general is still focused on the cognitive sphere and provide less opportunities for the development of creativity. In fact, education has a role and strategic function in order to produce the children's creativity, as the sound of Law Republic of Indonesia No. 20 of 2003 on National Education System Article 3, which states that "the purpose of national education is to develop the ability and shaping the character and civilization of the nation in order to educate the life of the nation, aims for the development of potential learners in order to become a man of faith and piety towards God Almighty, noble, healthy, knowledgeable, capable, creative, independent and become a democratic and responsible citizen". Saparahayuningsih (2010) argued that the purpose of education in general is to provide an environment that allows students to develop intelligence, creativity, skills and life skills what is needed by society and able to plunge in society both as individual and social. In the past, people craved that the success of a person is on intelligence. But now it is realized that the determination of success is not only intelligence but creativity and achievement motivation (struggle) (Saparahayuningsih, 2010). The results of Torrance (1959) showed that creativity and intelligence determine the achievement of school and other achievements. The implication for education is that student's achievement in school or achievement of any person need to be developed by the intelligence and creativity. Palaniappan (2006) argues that creativity is very important to be developed, because the creativity can improve academic achievement. This means that the improvement of students' achievement cannot only be done through educational process strategy tend to intelligence but also through learning strategy tend to creativity (Saparahayuningsih, 2010). Urgency of creative thinking capability contained in Law No. 19 of 2005 on National Education Standards Article 19 paragraph 1 that "the learning process in the educational unit held interactively, inspiration, fun, challenging, and motivate learners to participate actively, and provide sufficient space for initiative, creativity and independence in accordance with the talent, interests and physical and psychological development of learners". Then Mulyasa (2009) argued that the low ability of creative thinking resulted to the difficulty of students on solving problems. Based on the report of Minh (2015) the creativity was defined as the discovery or creation of a new idea that has never existed before. Creativity also means all the unique productive endeavors of the individual. So, the world of creativity education is very important in understanding a lesson or meaning of all activities that will be done. That's why the development of creativity should be done from an early age or from primary school (SD) (Budiarti, 2015). Child creativity will grow if the school can provide that creativity space. In the concept of friendly school's program, the educational institutions are not only demanded to provide protection to students from violence, discrimination, and other unnatural treatment, but the school must also be able to provide guarantees, meet, respect the rights of students including giving space for students to creativity in education. To provide space for creativity to children, an open school concept is required and trying to apply learning that takes the psychological development of their students. Muchsin, et al (2010) suggests that from the pattern of child-friendly education, it will bear children who are not only intelligent intellectual, but also intelligent conscience. Intellectual intelligence alone only makes the students like robots, so that this intellectual intelligence needs to be harmonized with the silence of his conscience. Utari (2016) argues that the principle of child-friendly schooling is to make students' interests and needs a primary consideration in defining every decision and action taken by educational managers and providers. Aqib (2008) suggests that child-friendly school models prejudice both children, teachers are aware of the different potentials of all learners, it to give students the 
opportunity to choose activities that suit their interests (Kristanto, Khasanah and Karmila, 2011). In this case childfriendly education not only focuses on the implementation of learning process that nullifies the practice of repressive style to the students, but also to every policy of the educational manager that makes him lose his fundamental rights as the subject of education. Child Friendly Schools should respect the rights of students when expressing their views on everything, especially about science, technology, art, and culture, so the students feel comfortable and fun in the learning process at school (Utari, 2016). In addition, childfriendly schools should ensure every student's opportunity to enjoy his/her rights in education without discrimination based on disability, gender, ethnicity, religion, type of intelligence, and parental background. Child-friendly schools should also consider safe, clean and healthy school situations, caring and cultured, living environment, respect the rights and protection of students from violence, discrimination and other unfair treatment, and ensure the participation of students in planning, policy, learning, supervision, and complaint mechanism related to the fulfillment of rights and protection of students in education (Iskandar, 2015). SD Negeri 109 Palembang is a school institution that has redesigned its school planning into a child-friendly school. It is manifested with various supporting indicators, such as Vision \& Mission, extracurricular program, teachers' training related to learning, playing facilities, talent interest and various other supporting indicators. In the learning system at SD Negeri 109 Palembang requires all teachers to have a fun teaching ability by using Active, Innovative, Creative, Effective, and Exciting Learning system. This is done to produce the fun teaching and learning activities and the students do not feel bored. Thus, the lessons taught can be easily accepted by the students. Likewise with the school environment at SD Negeri 109 Palembang designed in such a way as to provide space and stimulate the creativity of children.

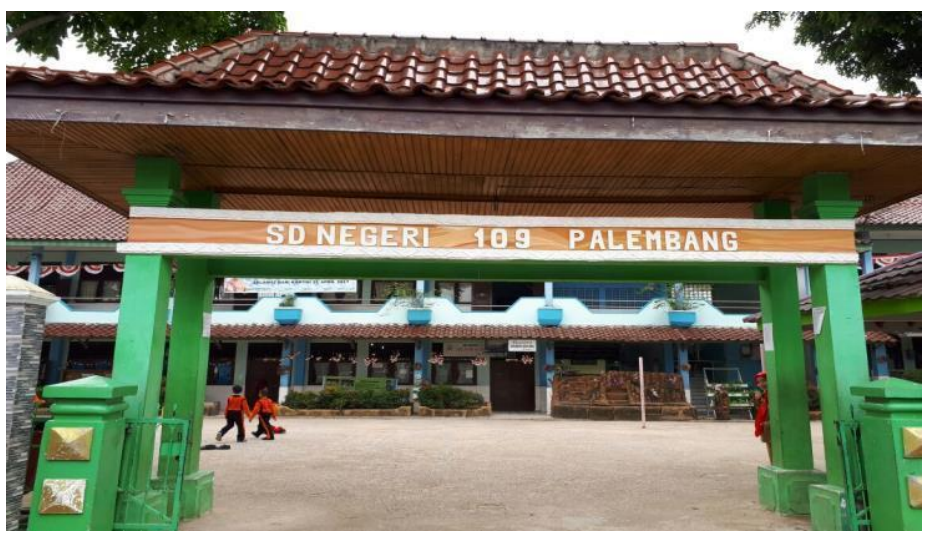

Figure 1. SD Negeri 109 Palembang

\section{STUDENTS' CREATIVITY}

The need for creativity is increasingly felt in the life of any world, whether in the corporate world, entertainment, health, politics, culture and social. Without a meaningful creativity, everything will be left behind by the development of dynamic world. For example if a company or entertainment product is always monotonous or no new creativity then the consumer will increasingly disappear because of boredom and switch to other products. Especially, in this global era and information, competition is getting tighter and changes occur dynamically, people tend to move on to other things that are felt more meaningful to them. So that this nation is not left behind and become a spectator against the dynamics of this world then creativity and intelligence of children need to be developed (Saparahayuningsih, 2010). Creativity can be interpreted as one's ability to think in generating new ideas that are effective and ethical. Creativity always refers to one's competence to find something that has never existed (Suratno, 2009). Thus, individual creativity is needed because creativity can generate innovation, and through creativity the human life becomes full (Suryadi, 2010), because creativity is the ability to think about something in a new and unusual way and produce a unique solution on various issues (Semiawan, 1999). Susanto, (2012) states that creativity as a person's ability on producing something new, both in the form of ideas and real work, which is relatively different from what has been there before. Pusitaningtyas, (2016) argues that creativity as a general ability to create something new, as the ability to provide new ideas that can be applied in problem solving, the ability to see new relationships between pre-existing elements. Maslow (1996) says the source of creativity is the tendency to actualize oneself, realize the potential, the impulse to grow and mature, the tendency to express and activate all the abilities of the organism yourself with nature, and with others. Then Hulbeck (1945) says that creative action is an imposing of one's own personality on the environment in a unique and characteristic way. Creativity is a daily activity associated with the activities of individuals or groups in a community so by developing creativity, it is expected students can solve problems independently or groups. This creativity is created in all areas and creativity can be taught in schools, because everyone basically has creativity. The creativity is the person's ability to produce something new, both in the form of ideas and real work, which is relatively different from what has been there before (Budiarti, 2015). The success of creativity according to Amabile (1987) is an intersection between the skills of the child in a particular field (domain skills), thinking skills and creative work, and intrinsic motivation. The intersection of creativity called creativity intersection, it can be described as follows.

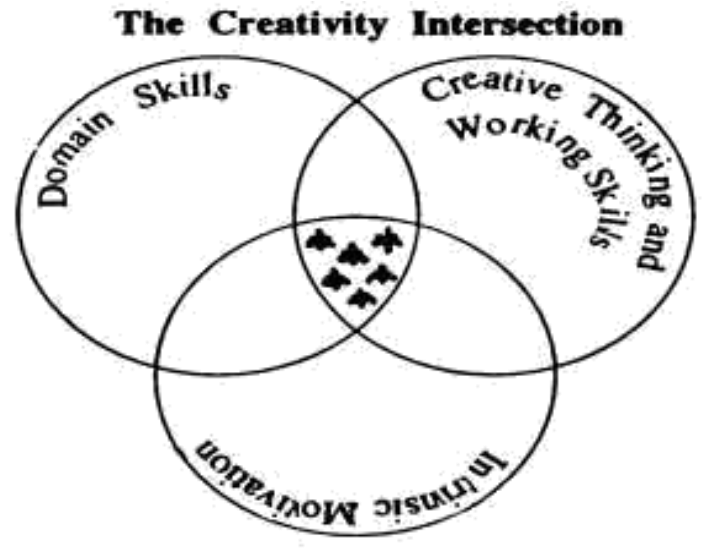

Figure 2. The Creativity Intersection

The characteristics of creativity can be viewed from two aspects (1) cognitive aspects, the characteristics of creativity associated with the ability to think creatively/divergent (aptitude characteristics) are (a) fluency; (b) flexible / flexible thinking skills; (c) Original thinking skills; (d) elaboration skills; 
and (e) evaluation skills. The more creative a person has, the more characteristics they have; (2) the affective aspect, the characteristics of creativity that are more related to one's attitude and feelings (non-aptitude characteristics) are (a) curiosity; (b) imaginative / fantasy; (c) feel challenged by pluralism; (d) the daring nature of taking risks; (d) the nature of respect; (e) confidence; (f) openness to new experiences; and (g) stand out in one of the arts (Williams, 1999). Munandar (2009), mentioned that the expected characteristics of creative personality are (1) broad and deep curiosity, (2) often asking good questions, (3) giving ideas or suggestions to a problem, ( (5) has a deep sense of beauty, (6) stands out in one area of art, (7) able to see a problem from various points of view, (8) has a great sense of humor, (9) has the power of imagination, (10) original in the expression of ideas and in problem solving. Semiawan (1999) suggests the characteristics of creativity among others are (1) dare to take risks, (2) play a positive role of creative thinking, (3) formulate and define problems, (4) grow up problem solving, (5) tolerance to ambiguity and (6) respect for others and the environment. Then, Sund (1975) states that individuals with creative potential can be known by observing the following characteristics (1) craving curiosity, (2) being open to new experiences, (3) reasoning, (4) find and examine, (5) tend to prefer tough and difficult tasks, (6) tend to seek broad and satisfactory answers, (7) have passionate and active dedication in performing tasks, (8) flexible thinking, (9) the ability to make an analysis, (10) have a passion for questioning and research, (11) have a good absorptive power, and (12) have a fairly wide reading background. Amabile (1987) suggests four ways that can kill creativity, evaluation, reward, competition between children, and restrictive environments. Meanwhile, according to Torrance (1989) are (1) too early attempt to eliminate fantasy; (2) restrictions on child curiosity; (3) overemphasizing roles based on sexual differences; (4) prohibits too much; (5) fear and shame; (6) an erroneous emphasis on certain verbal skills; and (7) provide a destructive criticism. The curriculum should be oriented to the learning experience in accordance with the principles of learning throughout the lifetime that refers to the four pillars of universal education as formulated by Unesco namely (1) Learning to Know (2) Learning to Do, (3) Learning to Be, 4) Learning to Live Together (Sanjaya, 2007). From the four pillars formulated, it appears in there is a shift of meaning to the educational process from simply knowing the information into the process of searching and utilizing information in order to encourage students' creativity in learning. Learning process will be successful when students have motivation and creativity. Therefore, teachers need to foster motivation and encourage students' learning creativity. To obtain optimal learning outcomes, teachers are required to generate creative motivation and encourage student learning creativity. Motivation and creativity of students can be encouraged by teachers, among others by (1) clarify goals to be achieved, (2) generate interest and creativity, (3) create a fun atmosphere in learning, (4) give a reasonable praise of each student's success, (5) give an assessment, (6) comment on student's work outcomes, (7) create competition and cooperation (Budiarti, 2015).

\section{FRIENDLY SCHOOL'S PROGRAM}

The word child-friendly began to flourish after the adoption of the Rights of the child by the United Nations which was then clarified by almost all UN members in 1989. The History of the
Rights of the Child as a direct descendant of Human Rights is one of the long historical journeys of the history of human rights struggle. After World War II that caused the number of children who became victims, in 1979 formed a working group to formulate the rights of children. The working group then formulated the Rights of the Child which later on 20 November 1989 was adopted by the United Nations and ratified as International Law through UN convection signed by UN member (Kristanto, Khasanah, Karmila, 2011). Then the childfriendly word begins in adoption in the world of education, where schools that can create a pattern of education that is conducive for children both for the growth and development of children can be categorized as child friendly school. Kristanto, Khasanah and Karmila (2011) argue that child-friendly schooling is an open school concept, trying to apply learning that takes the psychological development of their students. Developing learning habits in accordance with the natural and psychological conditions of children. Ulfah (2010) states that child-friendly education is a pattern of education that uses a gender perspective, the educational model that requires justice, both men and women. That is, the cultivation of values in the educational process of children is emphasized on the understanding that the characteristics of feminism and masculine traits have an equally important value in social life. This gender justice education should start from children, even babies. This means that a child is required to be critical and not to distinguish between the sexes. Arismantoro, (2008) argues that child-friendly education is education that creates a conducive learning environment so that children can learn effectively in an atmosphere that provides a sense of security, rewards without threat, and encouragement. Ngadiyo (2013), child-friendly education is an anti-discriminatory education, care and protects children, a healthy environment, and parent and community participation. Muchsin (2010) states that the pattern of child-friendly education is a form of education that treats children as living subjects, has the right to expression, enjoyment rights, the right to play, the right to inclusive communication, and the right of democratization. Yulianto (2016) suggests that a region may be included in the childfriendly category if it has the following characteristics (1) the child is involved in making decisions about the future of himself, his family and his environment, (2) the ease of obtaining basic services education, health and other services to grow, (3) open space for children to gather, play and create with their peers safely and comfortably; (4) the existence of rules that protect children from violence and exploitation; 5) absence discrimination in any case related to race, religion and class. Kristanto, Khasanah and Karmila (2011) suggest that there are several characteristics of child-friendly schooling (1) attitudes towards students, fair treatment for male and female students, intelligent-weak, rich-poor, normal-disabled, child labor-officials, application of local religious, social and cultural norms, and affection to students; (2) learning method, there is an effective learning process generated by the application of varied and innovative learning methods; (3) learning facilities, teaching and learning process is supported by teaching media such as textbooks and teaching aids or visual aids to help students absorb; (4) student involvement, students are involved in various activities that develop competence by emphasizing learning by doing (demo, practice, etc.); (5) classroom arrangement, disciples are involved in the arrangement of benches, decorations and illustrations depicting science, and so on; (6) classroom 
environment, students are involved in expressing their ideas in creating a school environment (classroom wall, decoration, suggestion box, wall magazine, school garden), clean water, hygiene and sanitation facilities, hygiene and health facilities, sanitation facilities such as toilets, adjusted to the posture and age of the child.

\section{RESEARCH METHOD}

This research used qualitative with descriptive method. Moleong (2013) defines qualitative research as research that intends to understand the phenomenon of what the research subjects experience by the description in the form of words and language, in a natural context and utilizing various scientific methods. According to Kristiawan \& Tobari (2017) qualitative concerned with process rather than simply with outcomes or product; qualitative research tend the analysis their data inductively; and "meaning" is the essential. The place of research is done in SD Negeri 109 Palembang. Data collection techniques used to obtain data in this study using observation, interviews, documentation and literature review related to this research. The validity of the data is done by source triangulation. Data analysis technique were using Miles and Huberman (1989) consist of data reduction, data display and data verification.

\section{RESULTS AND DISCUSSION}

The results revealed that the school provided space for students' creativity through learning strategy and school's environment approach. The Learning activities in the classroom used an active, innovative, creative, fun approach with quantum teaching and quantum learning and Student Active Learning (SAL) and Contextual Teaching and Learning (CTL) learning. SD Negeri 109 Palembang views that if the classroom atmosphere can be conditioned into a fun class, it can provide creative stimulation, and learning activities encourage students to be active, then creativity will emerge by itself. Dimyati and Mudjiono (2006) suggest that classroom learning can be done by (1) creating an orderly learning in the classroom, (2) creating a fun atmosphere in learning, (3) focusing on teaching materials, (4) engaging students in active learning, (5) organizing learning according to the condition of the students.

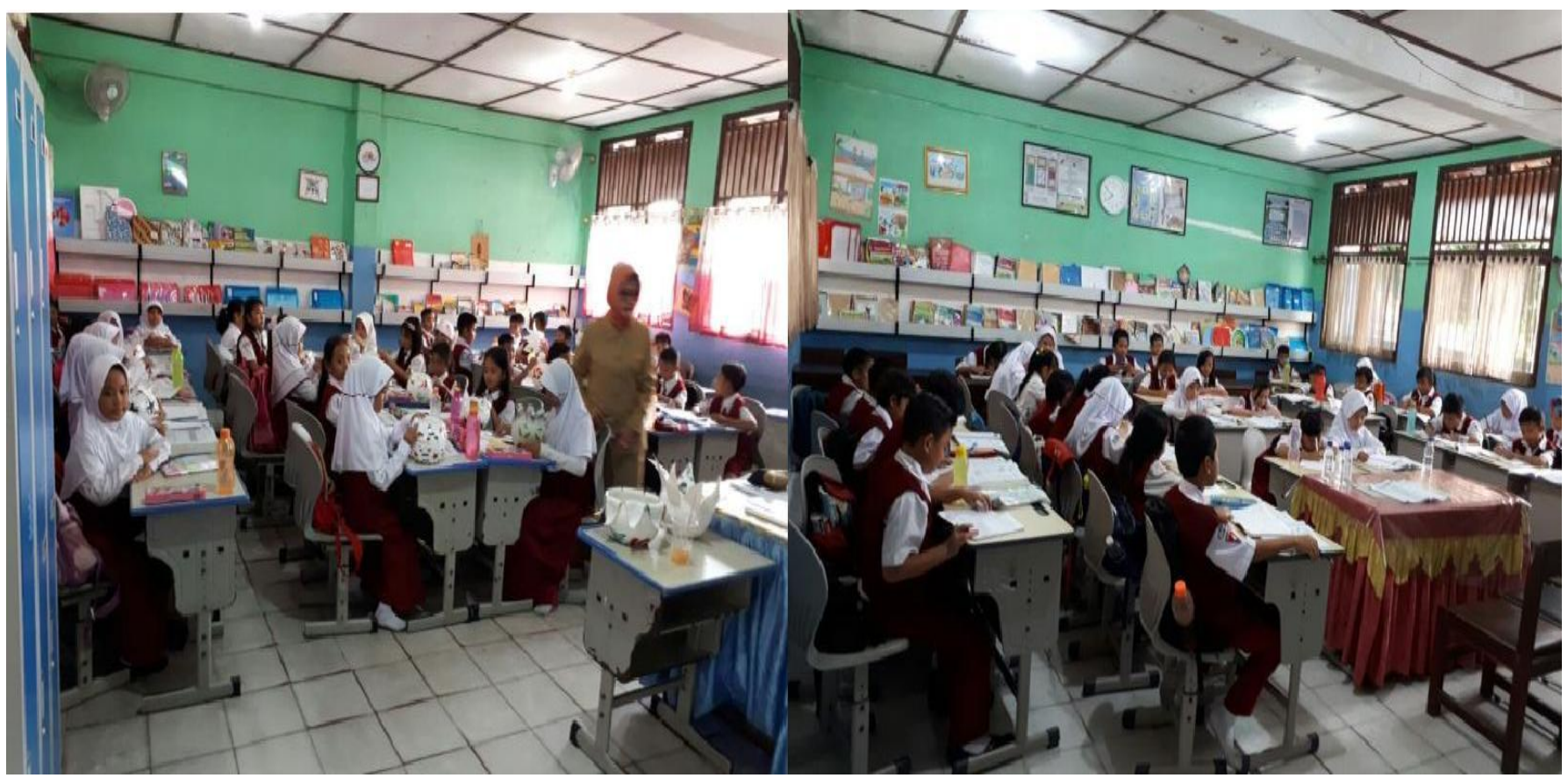

Figure 3. Creative Learning Atmosphere in SD Negeri 109 Palembang

In addition, SD Negeri 109 Palembang assess that if students have ability in all aspects of both the physical aspects, intellect, social-emotion and attitude and values, the ability will be able to support students' creativity. The greater of the student's achievement changes, the greater of the creativity that arises from within the student. As proposed by Soemantri (2011) the learning is a mental process expressed in a variety of behaviors, both physical-motor and mental behavior. Although, a learning activity is physical-motor but in it goes mental activity, and vice versa. These aspects of development can be differentiated but in fact difficult to separate. Something always has to do with other aspects. The effort was made by school in providing creativity space to students is by making the teacher as a facilitator for students. Thus, students are required to work together to find solutions and solving problems both individual and groups in the classroom, with the following steps (1) making each subject a problem generalization; (2) problem-solving approach with creative dialogue in reviewing generalization. Dimyati and Mudjiono (2006) say that learning can be done in several ways (1) individual learning, teachers act as facilitators, counselors, diagnoses of learning difficulties, and peer discussion; (2) group learning, orientation and the main emphasis of its implementation to improve the ability of cooperation and leadership. Through this learning approach, SD Negeri 109 Palembang attempts to provide direct instruction for children's creative ability. It can be developed through a learning process that is more focused on the development of right brain function. This is in accordance with the opinion of Pusitaningtyas (2016) that developing creative ability is the 
effort of developing right hemisphere brain function which concerns the ability of holistic, imaginative, intuitive and creative thinking through the learning process which is always identical with the fulfillment of linear, exact and logical. Fasko (2011) states that the ability to think creatively can be developed through direct instruction. To optimize the effort to give space for students' credibility, in the process of teaching and learning, teachers are also required to have creativity. Teachers are able to overcome the diversity of characteristics, abilities and dynamics of students' development. Psychologically, no two individual students are exactly alike, there is diversity. Therefore, teaching is a science and art. There is a teaching science, but that alone is not enough, it also needs art of teaching. The art of teaching is the creativity of teachers to find an approach that allows each student to develop the potential, skills and characteristics optimally (Sukmadinata, 2004). Then Budiarti (2015) argued that the interaction of teachers and students in the class that are considered capable of developing students' creative skills (1) respecting for unusual questions; (2) respecting the imaginative ideas of students; (3) giving students the opportunity to learn on their own initiative; (4) reward students; and (5) taking the time for students to learn and be busy without judgment. This is in accordance with the concept of child-friendly school adopted by SD Negeri 109 Palembang. Where the principle of learning strategy is done more centered on the students. This principle implies that in the learning process, students occupy a central position as a subject of learning. The success of the learning process is not measured by the extent to which the subject matter has been submitted by the teacher but the extent to which the students have been engaged in searching and finding the subject matter themselves (Budiarti (2015). The school environment approach conducted by SD Negeri 109 Palembang in an effort to provide space for students' creativity is by designing schools in accordance with the world of children. There is a playground, a hall for student activities and there are canteen, cooperatives, field and so forth. In addition, SD Negeri 109 Palembang also builds a good communication pattern, between students with teachers, students with employees, and teachers with employees. SD Negeri 109 Palembang assesses that the environment has a certain meaning or influence to the individual. Therefore, the school builds the atmosphere and culture of the environment, the school can provide a sense of security, increase interest and curiosity of children, give freedom of expression, can build self-confidence and self-actualization, can channel emotions, and can provide joy and pleasure to children who will certainly be able to stimulate the creativity.

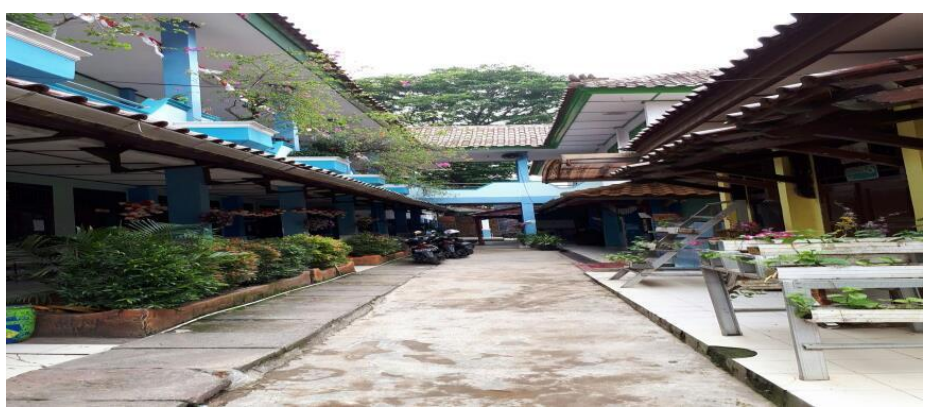

Figure 4. School Environment SD Negeri 109 Palembang with a Comfort and Clean Atmosphere

The school environment is expected to be able to support the students in developing their potential through teaching and learning activities that are done by providing facilities and conducive school environment conditions. A comfortable school environment will help students in following the teaching and learning process, because with a comfortable school environment, conducive facilities are adequate then students will also feel comfortable and calm in following the process of teaching and learning activities in school. School environment affects student learning outcomes, because it relates to students' comfort in learning process. School as a place of students to do learning process must create atmosphere and infrastructure that can support students in the learning process (Yulianto, 2016).

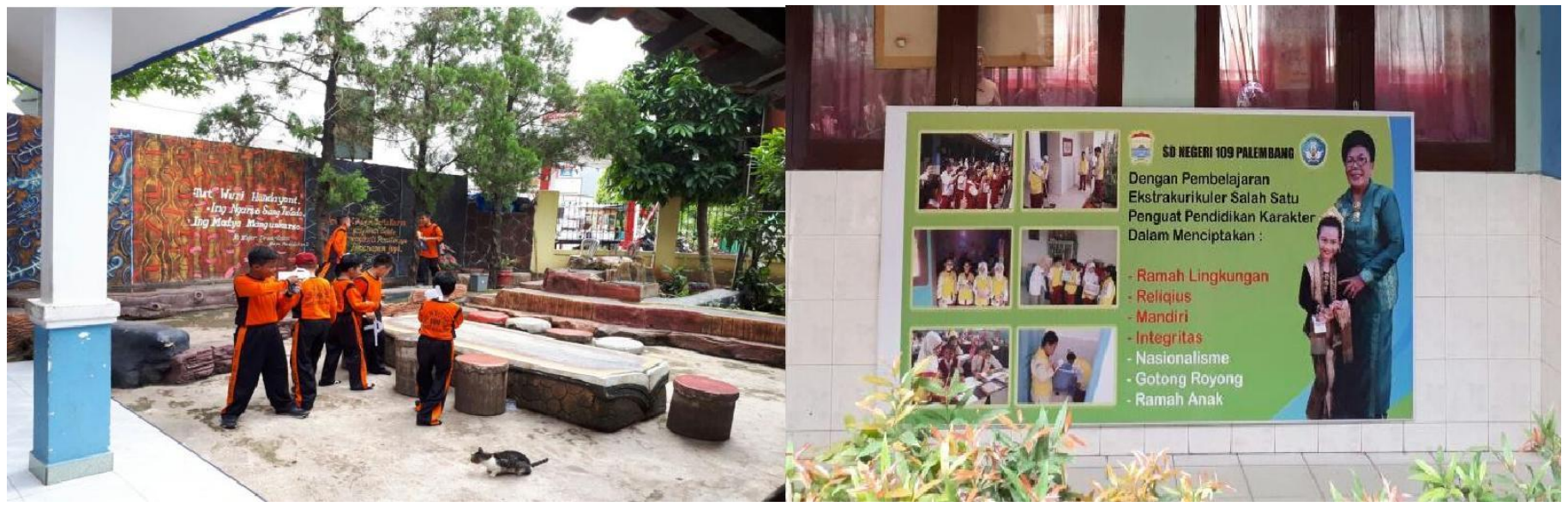

Figure 5. Environment Atmosphere in SD Negeri 109 Palembang

Through the approach of learning strategy and the school environment, the students of SD Negeri 109 Palembang become more enthusiastic in learning activities, not only that, the student of SD Negeri 109 Palembang also able to have good creativity in problem solving in learning process arranged by teacher, as well as outside learning activities such as drawing competitions and other arts that are routinely performed at the school. This means that the creativity of 
students can arise if the school is able to provide space to create the creativity. The learning process and the school environment are an important factor in an effort to provide space for students' creativity.

\section{CONSLUSION}

Student creativity can arise if the school is able to provide space for creativity. The learning process and school environment are important factors in providing space for students to be creative. Efforts to provide creativity space conducted by SD Negeri 109 Palembang, were through the approach of learning strategies and through the school environment approach. Learning activities in the child-friendly education program at SD Negeri 109 Palembang used an active, innovative, creative, fun learning approach with quantum teaching and quantum learning as well as learningbased Students Active Learning (SAL) and Contextual Teaching and Learning (CTL). The school environment conducted by SD Negeri 109 Palembang in an effort to provide space for students' creativity is by designing schools in accordance with the world of children. There is a playground, a hall for student activities and there are canteen, cooperatives, field and so forth. In addition, SD Negeri 109 Palembang also builds a good communication pattern, between students with teachers, students with employees, and teachers with employees.

\section{REFERENCES}

[1]. Amabile, T.M. (1987). The Motivation to be Creative. Frontiers of Creativity Research: Beyond The Basics. Buffalo, NY: Bearly Limited

[2]. Arismantoro. (2008). Character Building: How to Educate Children Character. Yogyakarta: Tiara Wacana.

[3]. Aqib, Zainal (2008). Child Friendly School. Jakarta: Yrama Widya.

[4]. Budiarti, Yesi. (2015). Development of Creativity Ability in Social Studies Learning. Journal of Economic Education UM Metro: 61-72.

[5]. Dimyati and Mudjiono. (2006). Learning and Learning. Jakarta: Rineka Cipta and the Ministry of Education and Culture.

[6]. Fasko, Jr. Daniel. (2011). Education and Creativity. Bowling Green State University: Creativity Research, Vol. 13, Nos. 3 \& 4, 317-327.

[7]. Hamalik, Oemar. (2005). Teaching Planning Based on System Approach. Jakarta: Earth Literacy.

[8]. Hulbeck, C. R. (1945). Oilpaintings, Watercolors, Drawings. Feigl Gallery.

[9]. Iskandar. (2015). Improving Creativity Teachers Learning, Jakarta: Bestari.

[10]. Juliantine, Tite. (2009). Student Creativity Development Through Implementation of Inquiry Learning Model In Physical Education. Faculty of
Physical Education and Health Indonesia University of Education

[11]. Kristanto, Ismatul Khasanah and Mila Karmila. (2011). Identification of child-friendly school model (sra) level of early childhood education unit in Southern Semarang sub-district. PAUDIA Research Journal, Volume 1 No. 1.

[12]. Kristiawan, M. (2017). The Characteristics of the Full Day School Based Elementary School. Transylvanian Review, 1 (1).

[13]. Maslow, Abraham, M. (1996). Motivation and Personality I (Motivation Theory and Human Needs Hierarchy Approach). Jakarta. PT. PBP.

[14]. Muchsin, Bastori. et al. (2010). Humanistic Islamic Education: Alternative Education for the Liberation of Children. Bandung: Refika Aditama.

[15]. Mulyasa. (2009). Becoming a Professional Teacher Creating Creative and Joyful Learning. Bandung: Teens Rosdakarya.

[16]. Moleong Lexy J. (2013). Qualitative Research Methodology. Bandung: PT.Remaja Rosdakarya.

[17]. Miles, Mathew B and Huberman, A. Michail. (1989). Qualitative Data Analysis. Jakarta: University of Indonesia.

[18]. Munandar, Utami. (2004). Development of Gifted Children Creativity. Jakarta: Bookkeeping Center of MoNE and Rineka Cipta.

[19]. Munandar, Utami. (2009). Development of Gifted Children Creativity. Rineka Cipta. Jakarta.

[20]. Munandar, Utami. (1999). Creativity \& Giftedness Strategy Achieving Creative Potential and Talent. Jakarta: Gramedia Pustaka Utama

[21]. Ngadiyo. (2013). Homeschooling, Raising Potential Children. Embun Magazine, 49-V-Rajab Edition 1434. May 2013.

[22]. Sanjaya, Vienna. (2007). Strategy of LearningOriented Standard Process of Education. Jakarta: Kencana Prenada Media Group.

[23]. Saparahayuningsih, Sri. (2010) Improving Students 'Intelligence and Creativity (Improving Students' Intelligence and Creativity). Journal of Basic Education Vol 1 No. 1. 1-5.

[24]. Semiawan, Conny R. (1999). Development and Learners Learners. Jakarta: Directorate General of Higher Education Teacher Education Project Primary School Department of Education and Culture.

[25]. Somantri, Numan. (2011). Initiating IPS Updates. Bandung: Postgraduate Masters and Teens Rosda 
Karya.

[26]. Sund, R.B. (1975). Teaching Science trough Discovery, 3rd Ed. Columbus: Charles E. Merrill Publishing Company.

[27]. Sukmadinata, N S. (2004). Curriculum and Competency Learning. Bandung: Kesuma Karya.

[28]. Suratno Tatang. (2009). Development of Student Creativity in Science Learning in Elementary School. Journal of Basic Education.

[29]. Suryadi, Edy. (2010). Effective Communication Model for the Development of Children Creative Thinking Ability. Journal of Communication Science, Volume 8, Number 3: 263-279.

[30]. Susanto Ahmad. (2012). Theory of Learning and Learning in Elementary School. Jakarta: Prenadamedia Group.

[31]. Torrance, E.P. (1989). Creativity What Research Says to the Teacher. Washington DC: National Education Association.

[32]. Torrance, E.P. (1959). Creativity What Research Says to the Teacher. Washington DC: National Education Association.

[33]. Law of the Republic of Indonesia no. 20 of 2003 on National Education System

[34]. Utari, E, Ranti. (2016). Implementation of Child Friendly School Program In SMP Negeri 1 Tempuran Magelang District. Journal of Education Policy Issue 7 Vol. V: 696-707.

[35]. Ulfah, Mary. (2010). Parenting With Love. The Islamic Guide educates children lovingly and affectionately. Bandung: PT Mizan Pustaka.

[36]. Palaniappan, Ananda Kumar. (2006). Academic Achievement of Groups Formed Based on Creativity and Intelligence. Journal. Malaysia. Universty of Malaya

[37]. PP no. 19 of 2005 on National Education Standards

[38]. Pusitaningtyas, Anis. (2016). The influence of parent and teacher communication on student creativity. Proceeding of ICECRS, 1 (2016) 935-942.

[39]. Williams, Bygrave, D. (1999). The Portable MBA In Entrepreneurship. New Jersey: John Wiley \& Sons Inc.

[40]. Yulianto, Agus. (2016). Child Friendly Education: A Case Study of SDIT Nur Hidayah Surakarta. Journal of Attarbawi, Volume. 1, No. 2 138-156. 